\title{
ANALYSIS OF RISK FACTORS OF CHRONIC KIDNEY DISEASE ON PATIENTS WITH HEMODIALYSIS IN TANGERANG DISTRICT HOSPITAL
}

\author{
Arman, Yusi Anggriani, Hesty Utami R \\ Pharmacy Student Pancasila University
}

\begin{abstract}
Chronic kidney disease (CKD) is a major world health challenge in the 21st centuries. The prevalence of CKD in Indonesia based on the doctor's diagnosis is $0.2 \%$ while for Tangerang prevalence at $0.1 \%$. There are no clear data of the predisposing factor of CKD on patient with hemodialysis (end stage renal disease) especially in Tangerang District. The purpose of this study was to analyze the risk factors CKD on patients with hemodialysis in Tangerang District Hospital. This study is an observational analytic research with casecontrol and cross sectional approach conducted in August to September 2017 at the Tangerang District Hospital. with 70 respondents in case group and 70 respondents in control group. The result of the bivariate analysis showed that 15 of 19 risk factors significantly $(p \leq 0.05)$ increased the risk of CKD with OR range 2.043 to 4.235. The result of multivariate analysis with logistic regression test showed that the most dominant risk factor for CKD was diabetes $(p=0.005)$ and hypertension $(p=0.032)$ with OR $4.000(95 \%$ C.I. 1.000-15.994) and 3.75 (95\% C.I. 0.274- 51.373) respectively. There are 15 risk factors that could increase the risk of CKD. the most dominant risk factor for CKD was diabetes and hypertension
\end{abstract}

Keywords: Risk factors, chronic kidney disease, hemodialysis

\section{ANALISIS FAKTOR RISIKO PENYAKIT GINJAL KRONIK PADA PASIEN HEMODIALISIS DI RSU KABUPATEN TANGERANG}

\begin{abstract}
ABSTRAK
Penyakit ginjal kronik (PGK) merupakan tantangan kesehatan utama dunia di abad 21. Prevalensi PGK berdasar diagnosis dokter di Indonesia sebesar 0,2 persen sedangkan untuk Kabupaten Tangerang prevalensi sebesar 0,1 persen. Belum ada data yang jelas tentang faktor penyebab PGK pada pasien hemodialisis khususnya di Kabupaten Tangerang. Tujuan dari penelitian ini adalah untuk menganalisis faktor risiko dari PGK pada pasien hemodialisis di RSU Kabupaten Tangerang. Penelitian ini merupakan penelitian analitik observasional dengan pendekatan case control yang dilakukan pada bulan Agustus sampai dengan September 2017 di RSU Kabupaten Tangerang dengan 70 responden kelompok kasus dan 70 reponden kelompok kontrol. Hasil analisis bivariat menunjukkan ada 15 dari 19 faktor risiko secara bermakna $(p \leq 0,05)$ meningkatkan kejadian PGK dengan kisaran OR 2,043 hingga 4,235_Hasil analisis multivariat dengan uji regresi logistik menunjukkan bahwa faktor risiko yang paling dominan untuk CKD adalah diabetes $(\mathrm{p}=$ $0,005)$ dan hipertensi $(\mathrm{p}=0,032)$ dengan OR masing-masing 4,000 (95\% C.I. $1.000-15,994)$ dan $3,75(95 \%$ C.I. 0,274 - 51.373). Terdapat 15 faktor risiko yang dapat menigkatkan risiko terjadinya PGK. Faktor risiko yang paling dominan adalah penyakit diabetes dan hipertensi.
\end{abstract}

Kata Kunci: Faktor risiko, penyakit ginjal kronik, hemodialysis

\footnotetext{
${ }^{1}$ Correspondece Address: Arman. Jl. Raya Lenteng Agung Timur, Srengseng Sawah, Jagakarsa, Jakarta Selatan Email:arman_apt@yahoo.com
} 


\section{INTRODUCTION}

Chronic kidney disease (CKD) is a major world health challenge in the $21^{\text {st }}$ centuries. ${ }^{1}$ Globally, CKD had high prevalence of $11-13 \%$ predominantly in stage 3 , as much as $7,6 \%{ }^{2}$ More than 7 million European had chronic kidney disease and 300,000 people had to underwent renal replacement therapy, either dialysis or renal transplantation. This prevalence was estimated to be increased 6-8\% each year. ${ }^{1}$

CKD prevalence based on doctors' diagnosis in Indonesia was 0,2 percent. The highest prevalence was in Central Sulawesi as much as 0,5 percent, followed by Aceh, Gorontalo, and North Sulawesi, each was 0,4 percent. ${ }^{3}$ CKD prevalence based on doctors' diagnosis in Banten Province was 0,2 percent. And prevalence for Tangerang District, Tangerang City, and Serang City was 0,1 persen. ${ }^{3}$

End stage renal disease (ESRD) patients would lost their renal function up to $90 \%$ or more, therefore, their bodies ability to maintain fluid and electrolyte balance was impaired, excretion function was inadequate, hormonal function was impaired and there was uremic or azotemia condition ${ }^{4}$. These conditions required chronic kidney disease patients to have renal replacement therapy. One of renal replacement therapy recently preferred and increased annually was HD.

Data in Indonesia showed that there was increased HD treatment, where in 2014 there was 703.267 treatment, compared with 2010 as much as 309.017 and 2007 as much as 104.211. New patients in 2014 were 17.193 while in 2010 it was recorded as much as 9.649 and in 2007 there was 4977 newly diagnosed patients. ${ }^{5}$

There were various causes for CKD in each country, the main cause of CKD in America was diabetes mellitus with incidence of $44 \%$, other risk factors were hypertension, glomerulonephritis, interstitial nephritis, systemic disease, neoplasms, etc. ${ }^{6}$ Results of conditional logistic regression analysis conducted by Delima et. al. had shown that advanced age, family history with CKD, consumption of drinking water $\leq 2000 \mathrm{ml} /$ day, consumption of soft drinks, energy drinks, having been diagnosed with glomerular or tubulo-intersisial kidney disorders, kidney stones, hypertension, and diabetes mellitus were increasing CKD risk with the adjusted OR range of 1,8 to 25,8 . Consumption of coffee, tea, chocolate, alcoholic beverages, non-steroidal antiinflammatory drugs (NSAIDs), traditional herb for pain, traditional slimming herbs, smoking, and poor drinking water quality were also factors that could potentially cause CKD. $^{7}$

The Indonesian Nephrology Association (Pernefri) noted that predisposing risks for CKD patients who underwent $\mathrm{HD}$ in 2014 were hypertension (37\%), diabetes mellitus or diabetic nephropathy (27\%), congenital abnormalities or primary glomerulopathy (10\%), urinary passage blockage disorders or obstructive nephropathy (7\%), gout (1\%), lupus (1\%) and other causes $(18 \%)^{5}$

Chronic kidney disease is a serious public health problem that need be prevented to reduce the increasing morbidity and mortality. To reduce the incidence of CKD, knowledge of predisposing risk factors is needed so that preventive measures could be taken as early as possible. There was no clear data about the causes of chronic kidney disease on patient with hemodialysis (ESRD) especially in Tangerang District, causing preventive measures not being done optimally and subsequently, the incidence of CKD will continue to increase. For this reason, risk factors for CKD in Tangerang District Hospital need to be examined to find their correlation with the incidence of CKD. The purpose of this study was to analyze risk factors for chronic kidney disease in patients with ESRD underwent hemodialysis in Tangerang District Hospital. 


\section{METHOD}

This study was conducted in Tangerang District Hospital which was conducted in September - November 2017. This study was analytic observational study with case control study design to look for the lifestyle of respondents who were considered as risk factors before respondents suffered from CKD. Case samples were groups of patients with chronic kidney disease and were undergoing outpatient hemodialysis at Tangerang District Hospital in the past year and fulfill inclusion and exclusion criteria.

Control samples were patients who were not diagnosed with chronic kidney disease. Case sample inclusion criteria were patients diagnosed with chronic kidney disease, age $\geq 18$ years, patients undergoing outpatient hemodialysis treatment at Tangerang District Hospital, closest relatives of patients if the patient's condition was not possible, willing to participate in the study by filling out and signing informed consent and was cooperative. The inclusion criteria for control samples were respondents who did not suffer from chronic kidney disease, age $\geq 18$ years, patients underwent outpatient treatment at the Tangerang District Hospital and were willing to participate in the study by filling out and signing informed consent and was cooperative. Exclusion criteria of study subjects were hospitalized hemodialysis patients, age $<18$ years, patients with a history of kidney transplants, not underwent outpatient treatment in the hemodialysis unit of Tangerang District Hospital and not willing to become respondents.

Comparison of case:control samples used was 1: 1 therefore sample size for cases group was 64 respondents and control group was 64 respondents, so total sample was 128 respondents. To avoid drop outs, an addition of $10 \%$ (12 samples) was added, with total of 140 samples, 70 samples in case group and 70 in control group. Data and data sources used in this study are primary data collected through questionnaires and interviews. The data needed recorded into the data collection sheet and then analyzed.

Statistical analysis used in this study was univariate, bivariate and multivariate analysis. Univariate analysis aimed to explain or describe characteristics of each study variable. Bivariate analysis was performed on variables thought to be related or correlated. Bivariate analysis was performed using logistic regression test to test the hypothesis of a significant relationship between risk factors and chronic kidney disease. Variables $\mathrm{p}<0.15$ from bivariate test were further analyzed to multivariate test by taking into account the possibility of interactions between variables. In this study, multivariate analysis was used to determine dominant risk factors for the incidence of chronic kidney disease in hemodialysis patients.

The basis to determine whether there was relationship was based on the error rate $\alpha$ $=0.05$, where significance value ( $\mathrm{p}$ value) of p> 0.05 showed that there is no relationship and if the $p$ value $<0.05$ then there is a relationship. Another analysis was used to see the independent variables, including to check for risk factors, was to by calculating odds ratio $(\mathrm{OR})$. If $\mathrm{OR}>1$, it meant that variable was a risk factor for CKD and if $\mathrm{OR}<1$, it meant that variable was not a risk factor.

\section{STUDY RESULT}

\section{Respondents' Socio-demographic} Characteristics and CKD Risk Factor Analysis

Characteristics of respondents in this study include age, gender, education level and occupation.

Socio-demographic characteristics of the subjects in the two groups are listed in table 1. Bivariate analysis of variables for chronic kidney failure could be seen in Table $1-4$. 
Table 1.

Sociodemographic characteristics of respondents and its correlation with CKD

\begin{tabular}{|c|c|c|c|c|}
\hline \multirow{2}{*}{ Variable } & Case $(N=70)$ & Control $(N=70)$ & \multirow{2}{*}{ OR (95\% CI) } & \multirow{2}{*}{$P$} \\
\hline & $\mathrm{n}(\%)$ & $\mathrm{n}(\%)$ & & \\
\hline \multicolumn{5}{|l|}{ AGE (Years) } \\
\hline $18-30$ & $2(2.86)$ & $11(15.71)$ & 1 & \\
\hline $31-40$ & $6(8.57)$ & $21(30.00)$ & $0.219(0.082-0.583)$ & 0.001 \\
\hline $41-50$ & $17(24.29)$ & $15(21.43)$ & $1.176(0.534-2.592)$ & 0.687 \\
\hline $51-60 *$ & $31(44.29)$ & $16(22.86)$ & $2.683(1.292-5.570)$ & 0.007 \\
\hline$\geq 61$ & $14(20.00)$ & $7(10.00)$ & $2.250(0.848-5.972)$ & 0.098 \\
\hline \multicolumn{5}{|l|}{ GENDER } \\
\hline Male & $34(48.57)$ & $35(50.00)$ & $0.944(0.487-1.832)$ & 0.866 \\
\hline Female & $36(51.43)$ & $35(50.00)$ & 1 & \\
\hline \multicolumn{5}{|l|}{ EDUCATION } \\
\hline Uneducated & $3(4.29)$ & $1(1.43)$ & $3.090(0.313-30.448)$ & 0.310 \\
\hline Elementary [6 years] $*$ & $10(14.29)$ & $3(4.29)$ & $3.722(0.978-14.164)$ & 0.042 \\
\hline Middle School [7-12 years] * & $42(60.00)$ & $29(41.43)$ & $2.121(1.080-4.163)$ & 0.028 \\
\hline College/University & $15(21.43)$ & $37(52.86)$ & 1 & \\
\hline \multicolumn{5}{|l|}{ OCCUPATION } \\
\hline Office work & $17(24.29)$ & $36(51.43)$ & 1 & \\
\hline Field work & $15(21.43)$ & $14(20.00)$ & $2.000(0.811-4.934)$ & 0.132 \\
\hline Working at home/jobless* & $38(54.29)$ & $20(28.57)$ & 4.235 (1.908-9.402) & 0.000 \\
\hline
\end{tabular}

The results of the study in table 1 showed that individual characteristics in most of respondents in case group were 51-60 years (44.29\%), while in control group mostly were $31-40$ years old $(32.86 \%)$. Gender distribution in both group were almost even, where male respondents were 34 people $(48.57 \%)$ and female were 36 people (51.43\%) in case group, while male and female in control groups each were 35 people $(50 \%)$.

Education level of respondents in this study were mostly middle school consisting of $60 \%$ of total respondents in case group and college/university graduates was $55.71 \%$ in control group. Respondents' occupation was mainly working at home / jobless (including self-employed) in the case group consisting of $54.29 \%$, while in the control group it was $28.57 \%$.

Bivariate analysis results describing age relationship, which were categorized into 18-30, 31-40, 41-50, 51-60 and > 60 years, with CKD using logistic regression tests, showed that there was significant relationship between age and CKD only at age 51-60 years with $p$ value $=0.007$. Age 51-60 years increased CKD risk by 2.683 times $(95 \%$ CI 1.292-5.570). From statistical test result for gender variables on CKD, it was found that there was no significant relationship $(\mathrm{p}=$ 0.866 ).

Elementary level of education had the strongest relationship and the highest risk as much as 3.722 times (95\% CI 0.978-14.164), while the middle school had a risk of 2.121 times (95\% CI 1.080-4.163). Respondents 
who did not go to school had an odds ratio of 3.090 yet had no significant relationship $(\mathrm{p}=$ 0.310). The results of bivariate analysis describing the relationship between occupation and CKD using logistic regression tests showed that working at home/jobless was the occupation that had significant relationship with CKD $(p=0.027)$. Working at home had CKD risk of 4.235 times $(95 \%$ C.I. 1.908-9.402).

\section{Overview of Respondents' Disease History and Behavior and Risk Factor Analysis of CKD}

Table 2 showed that history of diabetes and hypertension from respondents had significant relationship with the incidence of CKD, with $\mathrm{p}$ values of 0.014 and 0.004 , respectively. Diabetes had 3,100 times risk (95\% C.I. 1,260-7,629), while hypertension had 2,710 times risk (95\% C.I. 1,365-5,378) for developing CKD.

The result of this study found that predominant disease history in case group was hypertension, consisted of 41 people $(58.57 \%)$ and diabetes by $28.57 \%$, while in the control group, predominant diseases of respondents were hypertension as much as 24 people (34.29\%) and kidney disease by $18.57 \%$. Data from the $7^{\text {th }}$ report of Indonesian Renal Registry also showed that hypertension was the most common cause of CKD in hemodialysis patients in Indonesia, as much as $37 \%$ followed by diabetic nephropathy by $27 \% .^{5}$

Most of the case group respondents (67.14\%) used painkillers to treat pain, dizziness or headaches they experienced compared to the control group (48.57\%). While pain reliever such as traditional remedies were used by $20.00 \%$ of respondents in case group and $7.14 \%$ in control group. The highest frequency of consuming drugs in case group was once a day at $50 \%$ and in control group was three times per week at $15.71 \%$. The maximum duration of use of the drug was $3-5$ years, in $35.71 \%$ of the case group and in $25.71 \%$ of the control group.

The health supplements used mostly by respondents in this study were multivitamins and minerals, which consisted of $25.71 \%$ (18 people) of case group and $38.57 \%$ (27 people) of control group. The frequency of respondents using these supplements was generally at least once a day in the case group (34.29\%) and once a week $(27.14 \%)$ in the control group. Generally, respondents had used the supplement for 3-5 years $(32$ people $(45.71 \%)$ in the case group and 19 people (27.14\%) in the control group).

Table 2 showed that history of diabetes and hypertension from respondents had significant relationship with the incidence of CKD, with $p$ values of 0.014 and 0.004 , respectively. Diabetes had 3,100 times risk (95\% C.I. 1.260-7.629), while hypertension had 2.710 times risk (95\% C.I. 1.365-5.378) for developing CKD.

The use of painkillers had significant relationship with CKD incidence with $\mathrm{p}$ value of 0.027 . The use of these drugs increased CKD risk by 2.164 (95\% C.I. 1.091-4.290). From table 2 it could be seen that the frequency of using these drugs at least once a day will increase the risk of CKD by 2.043 times (95\% C.I. 1.031-4.051) with $p$ value of 0.040. Meanwhile, lesser frequency of use did not have significant relationship with the incidence of CKD ( $p>0.05$ ). From table 2 it could be found that the use of analgesics for a period of $>10$ years had significant relationship with the incidence of CKD $(\mathrm{p}=$ 0.042 ) and increased the risk of CKD to 3.722 times (95\% C.I. 0.978-14.164). 
Table 2.

Respondents' characteristics of disease history, habit of consuming analgetic, consuming health supplements and its correlation with CKD

\begin{tabular}{|c|c|c|c|c|}
\hline \multirow{2}{*}{ Variable } & Cases $(N=70)$ & Control $(\mathrm{N}=70)$ & OR (95\% C.I.) & $P$ \\
\hline & \multicolumn{2}{|r|}{ n $(\%)$} & & \\
\hline \multicolumn{5}{|l|}{ COMORBIDITIES } \\
\hline Diabetes * & $20(28.57)$ & $8(11.43)$ & $3.100(1.260-7.629)$ & 0.014 \\
\hline Hypertension [high blood pressure] & $41(58.57)$ & $24(34.29)$ & $2.710(1.365-5.378)$ & 0.004 \\
\hline Renal Disease & $11(15.71)$ & $13(18.57)$ & $0.817(0.339-1.974)$ & 0.654 \\
\hline \multicolumn{5}{|l|}{ ANALGETIC USE } \\
\hline Analgetic* & $47(67.14)$ & $34(48.57)$ & $2.164(1.091-4.290)$ & 0.027 \\
\hline Chinese remedies & $5(7.14)$ & $1(1.43)$ & $5.308(0.604-46.654)$ & 0.132 \\
\hline Traditional remedies* & $14(20.00)$ & $5(7.14)$ & $3.250(1.102-9.588)$ & $\mathbf{0 . 0 3 3}$ \\
\hline \multicolumn{5}{|c|}{ ANALGETIC CONSUMPTION FREQUENCY } \\
\hline At least once a day* & $35(50.00)$ & $23(32.86)$ & $2.043(1.031-4.051)$ & 0.040 \\
\hline 3 times per week & $11(15.71)$ & $12(17.14)$ & $0.901(0.368-2.205)$ & 0.820 \\
\hline 1 time per week & $6(8.57)$ & $5(7.14)$ & $1.219(0.354-4.195)$ & 0.753 \\
\hline 1 time per month & $3(4.29)$ & $4(5.71)$ & 1 & \\
\hline \multicolumn{5}{|l|}{ DURATION OF ANALGETIC } \\
\hline$<1$ year & $4(5.71)$ & $11(15.71)$ & 1 & \\
\hline $1-3$ year(s) & $14(20.00)$ & $10(14.29)$ & $1.500(0.616-3.651)$ & 0.370 \\
\hline $3-5$ years & $25(35.71)$ & $18(25.71)$ & $1.605(0.777-3.315)$ & 0.200 \\
\hline $5-10$ years & $2(2.86)$ & $2(2.86)$ & $1.000(0.137-7.305)$ & 1 \\
\hline$>10$ years $*$ & $10(14.29)$ & $3(4.29)$ & $3.722(0.978-14.164)$ & 0.042 \\
\hline \multicolumn{5}{|c|}{ HEALTH SUPPLEMENT CONSUMPTION } \\
\hline $\begin{array}{l}\text { Herbal supplement [Western and } \\
\text { Chinese] }\end{array}$ & $11(15.71)$ & $8(11.43)$ & $1.445(0.543-3.842)$ & 0.461 \\
\hline Traditional remedies* & $21(30.00)$ & $9(12.86)$ & $2.905(1.221-6.910)$ & 0.016 \\
\hline Drug concoction not factory-made & $5(7.14)$ & $4(5.71)$ & $1.269(0.326-4.939)$ & 0.731 \\
\hline Multivitamin and minerals & $18(25.71)$ & $27(38.57)$ & $0.551(0.268-1.133)$ & 0.105 \\
\hline \multicolumn{5}{|c|}{ HEALTH SUPPLEMENT CONSUMPTION FREQUENCY } \\
\hline At least once a day* & $24(34.29)$ & $13(18.57)$ & $2.288(1.050-4.984)$ & $\mathbf{0 . 0 3 5}$ \\
\hline 3 times per week & $11(15.71)$ & $7(10.00)$ & $1.678(0.610-4.616)$ & 0.313 \\
\hline 1 time per week & $10(14.29)$ & $19(27.14)$ & $0.447(0.191-1.049)$ & 0.061 \\
\hline 1 time per month & $4(5.71)$ & $9(12.86)$ & 1 & \\
\hline \multicolumn{5}{|c|}{ DURATION OF HEALTH SUPPLEMENT CONSUMPTION } \\
\hline$<1$ year & $3(4.29)$ & $11(15.71)$ & 1 & \\
\hline 1-3 year(s) & $9(12.86)$ & $8(11.43)$ & $1.143(0.414-3.158)$ & 0.796 \\
\hline $3-5$ years* & $32(45.71)$ & $19(27.14)$ & $2.260(1.116-4.580)$ & 0.022 \\
\hline $5-10$ years & $2(2.86)$ & $7(10.00)$ & $0.265(0.053-1.322)$ & 0.085 \\
\hline$>10$ years & $3(4.29)$ & $3(4.29)$ & $1(0.195-5.133)$ & 1.000 \\
\hline
\end{tabular}

Table 2 showed that consumption of health supplements such as traditional remedies could increase the risk of CKD by 2.905 times (95\% C.I. 1.221-6.910) with $\mathrm{p}$ value $=0.016$. While Western herbal supplements and Chinese herbs, concoction drugs that is not factory-made, and multivitamins and minerals did not have a significant relationship with the incidence of CKD ( $p>0.05$ ). The frequency of health supplements consumption that were too frequent (at least once a day) increased the 
risk of CKD by 2.288 times (95\% CI 1.050 4.984) with $\mathrm{p}=0.035$, while lesser frequency of consumption (three times a week, once a week and once a month) had no significant relationship with CKD incidence. The duration of supplement consumption which had a significant relationship with the incidence of CKD was 3-5 years $(\mathrm{p}=0.022)$, while longer use (5-10 years and >10 years) did not have significant relationship with the occurrence of CKD ( $p>0.05$ ).

In the case group, respondents who drank 8 glasses of water a day were $35.71 \%$ while in the control group were only $18.57 \%$. The source of water drank daily was generally from bottled water, as much as $37.14 \%$ in the case group and $48.57 \%$ in the control group. In addition to water, before being diagnosed with chronic kidney failure, other drinks often consumed by respondents were soft drinks (including coffee, tea, or chocolate) as much as $77.14 \%$ (54 people) in the case group and $85.57 \%$ (60 people) in the control group. Generally $(48.57 \%$ of the case group and $32.86 \%$ of the control group) the frequency of respondents consuming those beverage was at least once a day and respondents who had consumed the drink for $>10$ years was 9 people $(12.86 \%)$ in the case group and 17 people (24.29\%) in the control group.

Table 3.

Characteristics of water consumption habit, water source, drinks other than water and its correlation with CKD

\begin{tabular}{|c|c|c|c|c|}
\hline \multirow{2}{*}{ Variable } & Cases $(N=70)$ & Control $(N=70)$ & \multirow{2}{*}{ OR $(95 \%$ CI $)$} & \multirow{2}{*}{$P$} \\
\hline & n $(\%)$ & $\mathrm{n}(\%)$ & & \\
\hline \multicolumn{5}{|c|}{ AMOUNT OF WATER CONSUMED } \\
\hline $1-4$ glass(es) & $23(32.86)$ & $14(20.00)$ & \multirow{3}{*}{$\begin{array}{l}1.957(0.907-4.224) \\
0.288(0.143-0.578) \\
1\end{array}$} & \multirow{3}{*}{$\begin{array}{l}0.085 \\
0.000\end{array}$} \\
\hline $5-8$ glasses & $22(31.43)$ & $43(61.43)$ & & \\
\hline$>8$ glasses & $25(35.71)$ & $13(18.57)$ & & \\
\hline \multicolumn{5}{|l|}{ WATER SOURCE } \\
\hline Bottled water & $26(37.14)$ & $34(48.57)$ & $0.626(0.319-1.228)$ & 0.172 \\
\hline Refilled water & $25(35.71)$ & $16(22.86)$ & $1.875(0.893-3.937)$ & 0.095 \\
\hline Tap water [PDAM] & $12(17.14)$ & $15(21.43)$ & $0.759(0.326-1.764)$ & 0.520 \\
\hline Well water & $20(28.57)$ & $14(20.00)$ & $1.600(0.732-3.498)$ & 0.237 \\
\hline \multicolumn{5}{|c|}{ DRINKS OTHER THAN WATER } \\
\hline Softdrink & $54(77.14)$ & $60(85.71)$ & $0.563(0.235-1.345)$ & 0.196 \\
\hline Isotonics or energized water & $12(17.14)$ & $11(15.71)$ & $1.110(0.454-2.715)$ & 0.820 \\
\hline Alcohol & $4(5.71)$ & $1(1.43)$ & $1.376(0.451-4.196)$ & 0.573 \\
\hline Others & $2(2.86)$ & $4(5.71)$ & $0.485(0.086-2.740)$ & 0.413 \\
\hline \multicolumn{5}{|c|}{ BEVERAGE CONSUMPTION FREQUENCY OTHER THAN WATER } \\
\hline At least once a day* & $34(48.57)$ & $22(31.43)$ & $2.061(1.035-4.103)$ & 0.038 \\
\hline 3 times per week & $17(24.29)$ & $16(22.86)$ & $1.083(0.496-2.363)$ & 0.842 \\
\hline 1 time per week & $9(12.86)$ & $19(27.14)$ & $0.396(0.165-0.951)$ & 0.035 \\
\hline 1 time per month & $2(2.86)$ & $6(8.57)$ & 1 & \\
\hline \multicolumn{5}{|c|}{ DURATION OF BEVERAGE CONSUMPTION OTHER THAN WATER } \\
\hline$<1$ year & $10(14.29)$ & $12(17.14)$ & 1 & \\
\hline $1-3$ year(s) & $16(22.86)$ & $10(14.29)$ & $1.778(0.744-4.249)$ & 0.192 \\
\hline $3-5$ years & $5(7.14)$ & $15(21.43)$ & $0.260(0.089-0.755)$ & 0.009 \\
\hline $5-10$ years $*$ & $22(31.43)$ & $11(15.71)$ & $2.458(1.085-5.570)$ & 0.029 \\
\hline$>10$ years & $9(12.86)$ & $17(24.29)$ & $0.460(0.189-1.118)$ & 0.082 \\
\hline
\end{tabular}


Table 4.

Characteristics of food consumption habit and its correlation with CKD

\begin{tabular}{|c|c|c|c|c|}
\hline \multirow{2}{*}{ Variable } & Cases $(\mathbf{N}=70)$ & Control $(\mathbf{N}=\mathbf{7 0})$ & OR $(95 \%$ CI $)$ & $\boldsymbol{P}$ \\
\hline & $\mathbf{n}(\%)$ & $\mathrm{n}(\%)$ & & \\
\hline \multicolumn{5}{|l|}{ INSTANT/FASTFOOD CONSUMPTION } \\
\hline Fast food & $8(11.43)$ & $24(34.29)$ & $0.692(0.260-1.840)$ & 0.461 \\
\hline $\begin{array}{l}\text { Instant/canned food [noodles, soy sauce } \\
\text { and sardine] }\end{array}$ & $44(62.86)$ & $55(78.57)$ & $0.462(0.218-0.976)$ & 0.043 \\
\hline Processed meat/high fat & $15(21.43)$ & $35(50.00)$ & $0.273(0.130-0.571)$ & 0.001 \\
\hline $\begin{array}{l}\text { Fermented food [kimchi, tauco, miso, } \\
\text { cheese] or containing fermented } \\
\text { ingredients }\end{array}$ & $3(4.29)$ & $6(8.57)$ & $0.821(0.238-2.824)$ & 0.753 \\
\hline Others & $5(7.14)$ & $1(1.43)$ & $0.537(0.198-1.457)$ & 0.217 \\
\hline \multicolumn{5}{|c|}{ INSTANT/FASTFOOD CONSUMPTION FREQUENCY } \\
\hline At least once a day* & $23(32.86)$ & $12(17.14)$ & $2.365(1.066-5.248)$ & 0.032 \\
\hline 3 times per week & $14(20.00)$ & $23(32.86)$ & $0.511(0.237-1.103)$ & 0.085 \\
\hline 1 time per week & $23(32.86)$ & $22(31.43)$ & $1.068(0.525-2.171)$ & 0.856 \\
\hline 1 time per month & $2(2.86)$ & $10(14.29)$ & 1 & \\
\hline \multicolumn{5}{|c|}{ DURATION OF INSTANT/FASTFOOD CONSUMPTION } \\
\hline$<1$ year $*$ & $10(14.29)$ & $11(15.71)$ & 1 & \\
\hline $1-3$ year(s) & $17(24.29)$ & $9(12.86)$ & $2.174(0.895-5.283)$ & 0.082 \\
\hline $3-5$ years & $20(28.57)$ & $10(14.29)$ & $2.400(1.029-5.597)$ & 0.039 \\
\hline $5-10$ years & $1(1.43)$ & $15(21.43)$ & $0.053(0.007-0.415)$ & 0.000 \\
\hline$>10$ years & $13(18.57)$ & $22(31.43)$ & $0.498(0.227-1.092)$ & 0.079 \\
\hline
\end{tabular}

Mineral content in water was one of CKD risk factors. ${ }^{10}$ Contrary to previous study, this study found that water sources, which was categorized into bottled water, refilled water, tap water and well water, had no significant relationship with the occurrence of CKD ( $\mathrm{p}>0.05)$.

The result of this research showed that water consumption other than mineral water did not have significant correlation to CKD incidence ( $p>0.05)$. Although each type of beverage had no significant relationship with CKD, frequency of consumption particularly consumption at least a day increased the risk of CKD incidence by 2.061 times (95\% C.I. 1.035-4.103) with $\mathrm{p}=0.038$. The lesser frequency of beverage consumption had no significant relationship with CKD ( $>>0.05$ ). Long-term consumption of 5-10 years $(\mathrm{p}=$ 0.029) of these beverages had significant relationship with CKD which increased the risk by 2.458 times (95\% C.I. 1.085-5.570).

Most fast food consumed by respondents were instant/canned food and processed meat/high-fat foods, accounting for $50(71.40 \%)$ and $15(21.43 \%)$ respondents in case group, respectively, while in control group, these were $44(62.86 \%)$ and 35 $(50.00 \%)$, respectively. Instant/fast food consumption frequency in case group was at least once a day in 23 people (32.86\%), while in control group was generally three times a week in 23 people (32.86\%). Generally respondents of the case group (28.57\%) had consumed these food for 3-5 years, while control group was $>10$ years in $31.43 \%$.

Table 4 showed that canned food (corned beef, sardine) had potential to be the risk factor for CKD of 1.477 times (95\% C.I. 0.726-3.004) although this was not significant 
$(\mathrm{p}=0.281)$. This study also showed that frequent fast food consumption (at least once a day) also increased the risk of CKD occurrence by 2.365 times (95\% CI 1.066 5.248) with $\mathrm{p}=0.032$, while lesser frequency of consumption (three times a week, once a week and once a month) had no significant relationship with CKD incidence ( $p>0.05$ ). The duration of the food consumption for 3-5 years had significant correlation with CKD incidence $(\mathrm{p}=0.039)$ with odds ratio of 2.400 times (95\% CI 1.029-5.597), while longer duration (5-10 years old and > 10 years) had no significant relationship with the occurrence of CKD ( $p>0.05)$.

\section{Dominant Risk Factors}

Multivariable analysis using logistic regression test was used to determine the most dominant variable causing chronic kidney failure. Variables analyzed (bivariate analysis results with $p$ value $\leq 0.15$ ) were age 51-60 years old, age $\geq 61$ years old, elementary school, middle school, field work, working at home/ jobless, diabetes, hypertension, diabetes, analgesic use, chinese remedies, traditional remedies, frequency of medication at least once a day, duration of analgetic use, amount of water consumed, refill water source, frequency of drink consumption at least once a day, duration of beverage consumption, frequency of health supplements consumption at least once a day, consumption duration of health supplements, frequency of fast food consumption and consumption duration of fast food.

Multivariate tests result showed that dominant risk factors and had significant relationship with CKD in this study were hypertension $(\mathrm{p}=0.032)$ and diabetes $(\mathrm{p}=0.05)$. Hypertension could increase the risk of CKD by 3.75 times (95\% C.I. 0.274$51.373)$ and diabetes by 4.00 times (95\% C.I. 1.000-15.994). Although age 51-60 years and occupation was not significant for the incidence of CKD ( $p>0.05$ ), these variables had potential risk ( $\mathrm{p}<0.250$ ) of CKD with an odds ratio of 3.429 (95\% CI 0.818-14.369) and $8.000 \quad(95 \% \quad$ CI $\quad 0.598-106.936)$, respectively.

\section{DISCUSSION}

The results of the bivariate analysis showed that 15 risk factors were significantly ( $p \leq 0.05)$ increasing the incidence of CKD with a range of OR 2.043 to 4.235 . The highest risk factors are work at home/ jobless, elementary education level and duration of pain relief medication consumption.

In this study it was found that the incidence of CKD with hemodialysis had increased since age $>40$ years old. The results of the $7^{\text {th }}$ report of Indonesian Renal Registry also showed that the highest age group of hemodialysis patients were $45-54$ years and $55-64$ years (31\% respectively) while age group 0-14 years was 0\% and 15-24 years was $2 \%{ }^{5}$ Study by Delima et. al also found that the highest proportion of case group respondents was in the age group of 52-60 years. $^{7}$

Increased risk of CKD had occurred at the age of $>41$ years which was equal to 1.176 times (95\% CI 0.534-2.592) with $\mathrm{p}=$ 0.687 . From table 1 , it was also known that age > 60 also increased CKD risk twice but did not show a significant relationship. Study by Delima et al. also had the same tendency where increased age would increase the risk of developing CKD. ${ }^{7}$ This increased the risk of chronic kidney disease in the elderly. Study conducted by Lee et. al found that 41-64 years of age had a significant relationship with CKD $(p=0.001) .{ }^{11}$ Research in Iran also had the same tendency. ${ }^{12}$ Human physiology with aging would suffer from decreased quality of work, so does kidney which in the long term would have decreased number of nephrons and GFR. This increased the risk of CKD in the elderly.

From this study, it was known that men and women had the same risk to CKD. Many 
studies including Japanese Society for Dialysis Therapy showed that ESRD occured mostly in men. However, study conducted by CREDIT found that CKD was common in Turkish women (18.4 vs $12.8 \%) .{ }^{13}$ Najafi et. al. study also found that women had a higher risk of CKD than men. This was related to the BMI of women which tend to be higher than men. ${ }^{12}$ Thus, gender did not have a significant relationship with the incidence of CKD.

In this study the level of education were categorized to uneducated, elementary school, middle school (junior / high school) and college / university. Statistical test result in table 1 above found that significant level of education to CKD incidence was elementary school $(\mathrm{p}=0.005)$ and middle school $(\mathrm{p}=$ 0.028 ). From these results it was known that low level of education had a high risk level of CKD. The level of education was closely related to one's knowledge. ${ }^{14}$ The higher the knowledge of someone about health, the smaller the person's risk of disease occurrence for him. Najafi et. al. showed that the higher the education, the lower the risk of CKD at level of 3-5. ${ }^{12}$ Study by Lee et. al. showed that respondents with an education level < middle school had a CKD risk of 2.74 times compared to higher education. ${ }^{11}$

Working at home and jobless had less physical activity than other occupation. Physical activity had protective properties against the incidence of obesity and hypertension. Physical activity could control blood sugar thereby reducing the risk of developing diabetes which was a risk factor for CKD. The results of the RIKESDAS 2013 showed that the prevalence of diabetes (a risk factor for CKD) in the self-employed occupational groups tended to be higher than that of other occupational groups, this might be related to poor diet and lack of physical activity. ${ }^{3}$ Tabel 1 also showed that field worker (including laborers, marketing staff and general agrochemical drivers) also increased the risk of CKD twice (95\% CI 0.811-4.934) but did not show a significant relationship ( $\mathrm{p}=0.132)$. Laborers and other menial jobs were at risk of CKD because they were related to unhealthy eating and drinking patterns. Rubenstein et. al found that occupation with the highest risk of CKD was occupation in the legal and health fields with an OR of 6.14 and 6.08, respectively. ${ }^{15}$

History of diabetes and hypertension was a risk factor for CKD from the respondents of this study. Study conducted by Najafi et. al also showed the same results where diabetes increased the risk of CKD by 1.7 times and hypertension by 3.6 times. $^{12}$ Works by Lee et. al also showed a similar trend in which hypertension increased the risk of CKD by 2.43 times. $^{11}$ Diabetes mellitus, hypertension, glomerulonephritis, and nephrotic syndrome could cause oxidative stress to cells and stimulate an inflammatory response in the kidneys. Diabetes mellitus also aggravates kidney function through the action of the hormonal system reninangiotensin-aldosterone (RAA) which causes inflammation and scarring and fibrosis in the kidneys. ${ }^{16}$ In contrast to the research by Delima et. al which showed that kidney disease was a risk factor for CKD as much as 5.60 times, in this study we found that kidney disease (including kidney infection and kidney stones) of the respondents was not a risk factor for CKD with an OR of 0.817 (0.339-1.974).

RISKESDAS 2013 result found that the prevalence of joint disease / rheumatic / gout disease reached $11.9 \%$ based on diagnosis or 24.7 based on symptoms. The high prevalence of the disease will cause increased use of analgesic drugs (NSAID) which will have an impact on the increased risk of CKD. ${ }^{5}$ The study conducted by Ginawai et. al. found that $10.4 \%$ of people with high creatinine claimed to use NSAIDs continuously. ${ }^{17}$ Painkillers (NSAIDs) are nephrotoxic drugs. These drugs can cause inflammatory changes in the glomerulus, renal tubular cells, and adjacent the interstitium, causing kidney fibrosis and scarring. ${ }^{18}$ In contrast to the results of this 
study, the study conducted by Ingrasciotta et. al. found that Oxicam use increased the risk of CKD by 1.68 times (95\% CI $1.15-2.44$ ) specifically ketorolac (OR: 2.54; 95\% CI 1.45-4.44), meloxicam (OR: 1.98; 95\% CI 1.01-3.87) and piroxicam (OR: $1.95 ; 95 \%$ CI 1.19-3.21). There was no significant difference between the duration of use (3 months, 6 months and 1 year). ${ }^{19}$ In this study it was also found that consumption of herbal medicine as an painkiller was also a risk factor for CKD with an odds ratio of 3.250 (95\% CI 1.102-9.588) and $\mathrm{p}$ is 0.033. In contrast to this research, Delima et. al. found that the use of rheumatic traditional remedies was not a risk factor for CKD with $\mathrm{p}=0.159$ with an odds ratio of 1.42 times (95\% C.I. 0.87-2.29).

Research by Grubs et. al showed that the proportion of Americans using health supplements was $52.5 \%$ and $8 \%$ of them use supplements that potentially to have adverse effect to the kidneys. The most dangerous type of supplement was multivitamin and multi minerals, which was $3.4 \% .^{20}$ Health supplements have the potential to damage the kidneys. Grubs et. al. study showed that $14.3 \%$ of the supplements consumed by respondents had the potential to damage the kidneys where these supplements contained 18 of the 37 types of herbs identified by National Kidney Foundation as herbs that are harmful to the kidneys. ${ }^{20}$ One of the active ingredients in medicinal plants known to be toxic to the kidneys is aristolochic acid (AA) which can cause interstitial nephritis.

Although these supplements were consumed within 3-5 years, if consumed daily it would increase the risk of CKD. In contrast to this study, the study of Grubbs et. al showed that the frequency of dangerous supplement use was not significantly related to the respondent's CKD status. However, the study showed that the longer (> 3 years) duration of use of these supplements would increase the severity of $\mathrm{CKD}{ }^{20}$
The results of this study were different from those found in Delima et. al., where respondents who drink water $>2000$ liters per day in the case group were $15.9 \%$ which was smaller than control group, as much as $31.9 \% .^{7}$ Drinking behavior was associated with kidney function. Drinking enough water would reduce the possibility of forming kidney stones which could increase the risk of CKD. The results of the study revealed that the amount of water consumption did not have a significant relationship with the incidence of CKD $(p>0.05)$. Although not significant $(p=$ 0.085 ), total consumption of 1-4 glasses of water a day had the potential to increase the risk of CKD by 1.957 times (95\% CI 0.907 4.224). Delima et. al. found that habit of drinking water $<1000 \mathrm{ml} /$ day increased the risk of CKD as much as 7.69 times compared to people who drank $\geq 2000 \mathrm{ml} /$ day. ${ }^{7}$ Source of water used to drink daily was generally from bottled water, which was $37.14 \%$ in case group and $48.57 \%$ in control group. The mineral content of water was one of the risk factors for CKD. Wasana et. al found that high fluoride content in drinking water was associated with CKD events. ${ }^{10}$

The results of this study had the same tendency as the results of the RISKESDAS 2013 which showed that the proportion of the population with behavior of consuming risky drinks 1 times a day was $29.3 \%$ for coffee, $53.1 \%$ for sweet drinks and $5.6 \%$ for caffeine other than coffee. Risky beverage consumption was a behavior at risk for degenerative diseases. ${ }^{5}$ Although not significant, energy drinks and alcoholic beverages have potential risk of causing CKD. Alcoholic beverages had an odds ratio of 1.376 (95\% C.I. 0.451-4.196) while energy drinks were 1,110 (95\% C.I. $0.454-2.715)$. In the study by Delima et. al., the consumption of coffee or tea drinks did not show a significant relationship with CKD incidence $(p>0.05){ }^{7}$ Analysis result of studies in the United States in 194,095 participants showed that drinking caffeinated 
coffee or decaffeinated coffee or tea had a lower risk of developing kidney stones than carbonated sugary drinks. ${ }^{21}$ Sui-Lung Su study also showed that alcoholic drinks were not significantly associated with CKD events. $^{22}$

If those beverage had been consumed every day and consumed within 5-10 years, it would increase the risk of CKD. Research by Delima et. al also showed that CKD risk was increased in line with frequency of energy and carbonated drinks consumption in the range of 3.44 to 25.81 times. $^{7}$ Research by Ferarro et. al. also showed the same results where the more frequent carbonated sugary drinks was consumed, the higher the risk of CKD events would be. ${ }^{21}$ Sweeteners, preservatives and dyes in energy drinks made kidneys work harder. Kidneys worked hard in filtering these toxic materials and would result in kidney fatigue, which resulted in damage to the tubules and glomerules in the kidney and ended with CKD. ${ }^{23}$

This study had similar results with RISKESDAS 2013 showing that the number of people who consumed high-risk foods, i.e. food with high fat content and instant noodles $\geq 1$ times a day were $40.7 \%$ and $10.1 \%$, respectively, while in Banten Provinces this was $48.8 \%$ and $11.8 \% .^{5}$ Study by Syafni et.al found that western fast food most consumed by teenagers was fried chicken which amounted to $93.33 \%$ and around $22.2 \%$ of them consumed this food $>2$ times a week. ${ }^{24}$ High levels of sodium and preservatives found in fast food, especially instant noodles could aggravate kidneys function and damage kidneys.

From the results of this study, the consumption of fast food/instant food (fried chicken, burgers, instant noodles, soy sauce, high-fat foods, processed meat, canned food, fermented foods, and others) also had no relationship with $\mathrm{CKD}$ events $(\mathrm{OR}<1)$. Similar result was found in Syafni et. al. where the correlation test showed that there was no relationship between frequency, portion, nutrient content of western fast food (fried chicken, beef steak, pizza, cheese burgers, french fries and spaghetti) and western fast food contributions to systolic and diastolic blood pressure with $\mathrm{p}>0,05$.

Although these foods are not related to the incidence of CKD, if consumed at least once every day within 3-5 years it will increase the risk of CKD. Modern fast food could increase the risk of several diseases including kidney failure. Preferences and habits of people in consuming fast food also cause higher sodium intake because salt level was almost twice of the recommended normal level, that was <2.4 grams. High salt could affect people with impaired kidney conditions, and could be one of the cause of kidney failure. In addition, high levels of protein and phosphate in fast food will further damage the kidneys. $^{25}$

Processed foods such as corned beef, beef burgers and drinks are foods that contain high levels of phosphate. The risk of heart disease in CKD patients could increase with phosphate food consumption. Patients with CKD cannot excrete excess phosphate into the urine, so this would accumulate in the blood. This phosphate accumulation in the blood was a well-known risk factor for CKD, which increased the risk of heart disease in patients. According to a new study published in the Kidney International journal, chemicals used to produce canned layers of food could harm kidneys. $^{26}$

The dominant risk factor of this study was diabetes and hypertension. In the United States and Japan, hypertension and diabetes mellitus had also become main causes of CKD. ${ }^{16}$ Research conducted in Iran which was conducted by Najafi et al. also showed that hypertension was associated with an increased risk of CKD with OR $3.16(95 \% \mathrm{CI}$ $2.02-4.95)$ besides obesity $(\mathrm{OR}=1.78 ; 95 \%$ CI 1.04-3.05) and diabetes $(\mathrm{OR}=1.70 ; 95 \%$ CI 1.00-2.86). ${ }^{12}$ Multivariate test results from the study by Lee JS et. al. also showed that hypertension had the highest odds ratio 
compared to other risk factors, as much as 2.40 (95\% CI: $1.48-3.90)$ with $\mathrm{p}=<0.001 .11$ In addition, a case control study conducted by Hidayati in PKU Hospital Yogyakarta in 2008 showed that hypertension increased CKD risk by 23.15 (95\% CI 8.73-61.41). ${ }^{8}$

\section{CONCLUSION}

The bivariate analysis shows that 15 risk factors can cause CKD significantly and the dominant risk factor is diabetes and hypertension. Based on this study result, we hope that State Governmental program to control diabetes and hypertension particularly in Tangerang District could be more encouraged considering RISKESDAS 2013

\section{REFERENCES}

1. Brophy JM, Babapulle MN, Costa V, Rinfret S. A pharmacoepidemiology study of the interaction between atorvastatin and clopidogrel after percutaneous coronary intervention. Am Heart J. 2006; 152(2): 263-269. doi:10.1016/j.ahj.2005.08.023.

2. Bienaime F, Pontoglio M, Terzi F, Lee DC, Legendre C. A transcriptional network underlies susceptibility to kidney disease progression. Embo Mol Med. 2012; 4: 825-839. doi:10.1002/emmm.201101127.

3. Kementrian Kesehatan RI. RISET KESEHATAN DASAR. Jakarta; 2013.

4. Lestariningsih. Pelayanan Hemodialisis Dan Perkembangan Di Indonesia. In: Simposium Nasional Peningkatan Pelayanan Penyakit Ginjal Kronik Masa Kini Dan Indonesia Renal Registry. Yoyakarta; 2013.

5. Indonesia Renal Registry. 7 th Report Of Indonesian Renal Registry 2014. In: Jakarta; 2014.

6. Suwira K. Penyakit ginjal kronik. In: Sudoyo A, Setiyohadi B, Alwi I, Setiati S, eds. Buku Ajar Ilmu Penyakit Dalam. II. Jakarta: Pusat Penerbitan Ilmu Penyakit Dalam Diponegoro; 2009:10351040.

7. Delima, Idaiani S, Andayasari L, et al. Faktor Risiko Penyakit Ginjal Kronik: result showed that hypertension prevalence was $25.8 \%$ nationally and in Tangerang District was $23.6 \%$ which was second highest in Banten Province .

Furthermore, people's awareness was also required to be able to keep healthy and have a healthy lifestyle by avoiding lifestyle that can increase the risk of CKD events. By preventing and controlling these CKD risk factors, it was hoped that the morbidity rate of CKD would be decreased, particularly in Tangerang District. Further research is needed in several regions in Indonesia so that the risk factors for CKD are obtained nationally to prevent more comprehensive CKD events.

Studi Kasus Kontrol di Empat Rumah Sakit di Jakarta Tahun 2014. Bul Penelit Kesehat. 2017;45(1):17-26.

8. Hidayati, Kushadiwijaya, Suhardi. Pengaruh Hipertensi Merokok dan Minuman Suplemen Energi dan Kejadian Penyakit Ginjal Kronik. Berita Kedokteran masyarakat 2008;24(2):90102.

9. Asriani, Bahar B, Kadrianti E. Hubungan Hipertensi Dengan Kejadian Penyakit Ginjal Di Rumah Sakit Ibnu Sina Makassar Periode Januari 2011Desember 2012. Jurnal Ilmiah Kesehatan Diagnosis 2014;4(2):163-168.

10. Wasana HM, Kularatne WM. Drinking water quality and chronic kidney disease of unknown etiology $(\mathrm{CKDu})$ : synergic effects of fluoride, cadmium and hardness of water. Eviron Geochem Health 2016;38(1):157-168. doi:10.1007/s10653-015-9699-7.

11. Lee SJ, Chung CW. Health Behaviors and Risk Factors Associated with Chronic Kidney Disease in Korean Patients with Diabetes: The Fourth Korean National Health and Nutritional Examination Survey. Asian Nurs Res (Korean Soc Nurs Sci). 2014;8(1):8-14. doi:10.1016/j.anr.2013.11.001.

12. Najafi I, Attari F, Islami F, Shakeri R, Malekzadeh F, Salahi R. Renal Function and Risk Factors of Moderate to Severe 
Chronic Kidney Disease in Golestan Province, Northeast of Iran. PLoS One. 2010;5(12):1-6. doi:10.1371/journal.pone.0014216.

13. Kazancioğlu R. Risk factors for chronic kidney disease: an update. Kidney Int Suppl. 2013;3(4):368-371. doi:10.1038/kisup.2013.79.

14. Shoji T, Emoto M, Shinohara K, et al. Diabetes Mellitus , Aortic Stiffness, and Cardiovascular Mortality in End-Stage Renal Disease. J Am Soc Nephrol. 2001;12:2117-2124.

15. Rubinstein S, Wang $\mathrm{C}, \mathrm{Qu}$ W. Occupational risk and chronic kidney disease : a population-based study in the United States adult population. Int $\mathbf{J}$ Nephrol Renovasc Dis. 2013;6:53-59.

16. Tsukamoto Y, Jha V, Becker G, Chen H, Perkovic V, Prodjosudjadi W. A challenge to chronic kidney disease in Asia: The report of the second Asian Forum of Chronic Kidney Disease Initiative. Nephrology. 2010;15:248-252.

17. Ginawi IA, Ahmed HG, Al-hazimi AM. Assessment of Risk Factors for Chronic Kidney Disease in Saudi Arabia. IJSR 2014;3(7):446-450.

18. Naughton CA. Drug-Induced Nephrotoxicity. Am Fam Physician. 2008;78(6): 743-750.

19. Ingrasciotta Y, Sultana J, Giorgianni F, Fontana A. Association of Individual Non-Steroidal Anti- Inflammatory Drugs and Chronic Kidney Disease: A Population-Based Case Control Study. PLoS One 2015;10(4): 1-14. doi:10.1371/journal.pone.0122899.

20. Grubs V, Platinga L, Tout D. HHS Public Access Author manuscript Am J Kidney Dis. Author manuscript; available in PMC 2014 May 01. Published in final edited form as: Am J Kidney Dis. 2013 May ; 61(5): 739-747. doi:10.1053/j.ajkd.2012.12.018.

Americans' Use of Dietary Supplements That. Am J Kidney Dis. 2013;61(5):739747.

doi:10.1053/j.ajkd.2012.12.018.America ns.

21. Ferraro P, Taylor E, Gambaro G, Curhan G. Soda and Other Beverages and the Risk of Kidney Stones. Clin J Am Soc Nephrol. 2013;8:1-7.
22. Su S, Lin C, Kao S, et al. Risk factors and their interaction on chronic kidney disease: A multi-centre case control study in Taiwan. BMC Nephrol. 2015; 16(83):1-10. doi:10.1186/s12882-0150065-x.

23. Kumaini. Minuman Energi Bisa Sebabkan Penyakit Ginjal. http://jambi.tribunnews.com. Published 2012. Accessed January 17, 2017.

24. Syafni A. Hubungan Konsumsi Western Fast Food Dengan Hipertensi Pada Remaja Di SMA N 1 Semarang. Journal of Nutrition Collage 2015;4(4):358-164. doi: 10.14710/jnc.v4i4.10111.

25. Ibanez J. Fast Food and Signs of Kidney Problems. https://livekidneydonation.org/blog/fastfood-and-signs-of-kidney problems/. Published 2015.

26. Shutto Y, Shimada M, Kitajima M, et al. Inadequate Awareness among Chronic Kidney Disease Patients Regarding Food and Drinks Containing Artificially Added Phosphate. PLoS One 2013;8(11):1-4. doi:10.1371/journal.pone.0078660.Adde d Phosphate. PLoS One 2013;8(11):1-4. doi:10.1371/journal.pone.0078660 